\title{
The Extraction of Copper(I) Ions with Heterocyclic Bidentate Amines in the Presence of Glutathione
}

\author{
Kotaro MORITA, Kazuki NAKANO and Hisanori IMURA* \\ Division of Material Sciences, Graduate School of Natural Science and Technology, Kanazawa University, \\ Kakuma, Kanazawa 920-1192, Japan
}

(Received August 21, 2013; Accepted October 31, 2013)

Copper(I) ions are generally unstable in aqueous solution and readily disproportionate to copper(II) and copper(0). In this work, copper(I) is formed and stabilized under aerobic conditions by the addition of glutathione (GSH) which acts as a reducing and complexing agent. The extraction of $\mathrm{Cu}(\mathrm{I})$ with heterocyclic bidentate amines such as 2,9-dimethyl-1,10-phenanthroline (dmp), 2,9-dimethyl-4,7-diphenyl1,10-phenanthroline, and 2,2'-biquinoline has been studied in the presence of GSH. The formation of the $\mathrm{Cu}(\mathrm{I})-\mathrm{GSH}$ complex in the aqueous solution was confirmed by spectrophotometry under aerobic conditions. Time-course measurements of the absorbance indicated that the $\mathrm{Cu}(\mathrm{I})$-GSH complex retained stability toward re-oxidation by air for at least $6 \mathrm{~h}$ in the presence of a 10-fold excess of GSH at pH 5-7. The quantitative extraction of copper(I) was accomplished with $5.0 \times 10^{-4} \mathrm{M} \mathrm{dmp}$ in chloroform or 1,2-dichloroethane in the presence of $5.0 \times 10^{-4} \mathrm{M} \mathrm{GSH}$ and $0.10 \mathrm{M} \mathrm{ClO}_{4}^{-}$at $\mathrm{pH} 3-6$. The extracted species was found to be $\mathrm{Cu}(\mathrm{dmp})_{2} \mathrm{ClO}_{4}$ by the substoichiometric extraction method.

\section{Introduction}

Copper widely occurs in biological and geological materials and is found in different oxidation states, typically $0,+1$, and +2 , which depend on the chemical environment of copper in the materials. In biological systems, it is known that $\mathrm{Cu}(\mathrm{I})$ and $\mathrm{Cu}(\mathrm{II})$ exist and play an important role in redox and electron transport processes.

Since $\mathrm{Cu}(\mathrm{I})$ ions in aqueous solution is unstable and readily disproportionate to $\mathrm{Cu}(\mathrm{II})$ and $\mathrm{Cu}(0)$, any ligand that forms stable $\mathrm{Cu}(\mathrm{I})$ complexes is essential to prevent the disproportionation reaction. In the previous studies concerning the extraction of $\mathrm{Cu}$ (I), $\mathrm{Cu}$ (II) was reduced to $\mathrm{Cu}(\mathrm{I})$ using reducing agents such as hydroxylamine hydrochloride and ascorbic acid in the presence of chloride [1], thiocyanate [2,3], and halides[4] as the designated ligand $\left(\mathrm{X}^{-}\right)$and extracted with quaternary ammonium ions $\left(\mathrm{Q}^{+}\right)$into 1,2-dichloroethane and chloroform as an ion pair, $\mathrm{Q}^{+} \cdot \mathrm{CuX}_{2}^{-}$. On the other hand, the well-known bidentate ligands, 1,10-phenanthroline [5], 2,9-dimethyl-1,10-phenanthroline [6,7], and 2,9-dimethyl-4,7-diphenyl1,10-phenanthroline [8], have been employed for the spectrophotometric determination of $\mathrm{Cu}(\mathrm{I})$ after the reduction of $\mathrm{Cu}$ (II) with hydroxylamine and extraction into alcohol solvents. To the best of our knowledge, there is no study on the extraction equilibrium of $\mathrm{Cu}(\mathrm{I})$ with those ligands in spite of many spectrophotometric applications [9]. This was due to lack of knowledge of the stabilization of the $\mathrm{Cu}(\mathrm{I})$ species in not only the organic but also the aqueous phases in the equilibrium study. 
In this paper, glutathione (GSH) was used as the reducing agent for preparation of the $\mathrm{Cu}(\mathrm{I})$ solution. It is expected that the $\mathrm{Cu}(\mathrm{I})$ ions formed in the aqueous solution are stabilized under aerobic conditions with GSH which acts as a reducing and complexing agent. The effect of GSH on the stabilization of the $\mathrm{Cu}(\mathrm{I})$ state was examined and compared with those of common reducing agents, hydroxylamine and cysteine [10]. The extraction of the $\mathrm{Cu}(\mathrm{I})$ ion was studied with several heterocyclic bidentate amines such as 2,9-dimethyl-1,10-phenanthroline (dmp), 2,9-dimethyl-4,7-diphenyl-1,10-phenanthroline (dmdpp), and 2,2'-biquinoline (bq) in the presence of GSH. The formation of the $\mathrm{Cu}(\mathrm{I})$-GSH complex in the aqueous solution and the extraction equilibrium of $\mathrm{Cu}(\mathrm{I})$ in this system was studied. The composition of the extracted species was confirmed by the substoichiometric extraction of $\mathrm{Cu}(\mathrm{I})$ with a substoichiometric amount of dmp in the presence of an excess of a counter ion, $\mathrm{ClO}_{4}^{-}$, and vice versa.

\section{Experimental}

\subsection{Reagents}

GSH (Tokyo Chemical Industry, $\geq 97.0 \%$ ), dmp (Sigma Aldrich, $99 \%$ ), dmdpp (Tokyo Chemical Industry, $\geq 99.0 \%$ ), and bq (Tokyo Chemical Industry, $\geq 99.0 \%$ ) were used as received. Prior to use, 1,2-dichloroethane (DCE, Sigma Aldrich, $\geq 99.5 \%$ ) was washed with $3 \mathrm{M}$ sulfuric acid, $3 \mathrm{M} \mathrm{NaOH}$, and water. Chloroform (Nacalai Tesque, $99 \%$ ) was washed three times with<smiles>N[C@@H](CCC(=O)N[C@@H](CS)C(=O)NCC(=O)[O-])C(=O)O</smiles>

Figure 1. Chemical structure of monoprotonated glutathione $\left(\mathrm{GS}^{2-}\right)$ water to remove ethanol added as a stabilizer. 2-[4-(2-Hydroxyethyl)-1-piperazinyl]ethanesulfonic acid (HEPES, Dojindo, $\geq 99 \%$ ) and 2-morpholinoethanesulfonic acid monohydrate (MES, Dojindo, $\geq 99 \%$ ) were used to prepare buffer solutions. All other reagents were of commercially available analytical grade and were used without further purification. Water was deionized ( $\geq 18.0 \mathrm{M} \Omega \mathrm{cm}$ specific resistance) with an Elix UV Water Purification System and a Synergy UV system (Millipore Corp., Bedford, MA).

\subsection{Apparatus}

A Hitachi model Z-6100 polarized Zeeman atomic absorption spectrophotometer (FAAS) was used for the determination of $\mathrm{Cu}$ in the aqueous solutions. A Horiba model F-52 pH meter equipped with a combination glass electrode was used to determine the $\mathrm{pH}$ value. Absorption spectra were measured with a JASCO V-570 spectrophotometer using $1 \mathrm{~cm}$ quartz cuvettes. The time-course measurements of the absorbance were conducted with a Shimadzu UV-160 spectrophotometer.

\subsection{Preparation of copper (I, II) solutions}

$\mathrm{Cu}(\mathrm{II})$ stock solutions were prepared by dissolving $\mathrm{Cu}(\mathrm{II})$ chloride in $0.1 \mathrm{M}$ hydrochloric acid or $\mathrm{Cu}$ (II) sulfate pentahydrate in $0.05 \mathrm{M}$ sulfuric acid. Aqueous solutions of $\mathrm{Cu}(\mathrm{I})$ were prepared by adding a reducing agent such as GSH, cysteine, and hydroxylamine to the $\mathrm{Cu}(\mathrm{II})$ solutions. The reducing agents were dissolved in water just before use.

\subsection{Time-course measurement of the absorbance of $\mathrm{Cu}(\mathrm{I})$ in the aqueous solution}

Following measurements of change of the absorbance were carried out after 1 min of the addition of the reducing agent to the $\mathrm{Cu}(\mathrm{II})$ solution. Absorption spectra were recorded for $2 \mathrm{~h}$ at regular intervals and the absorbance changes at absorption maxima were also recorded for $12 \mathrm{~h}$. Several reducing conditions were examined at different molar ratios of the reducing agent to copper ([reducing agent $] /[\mathrm{Cu}]$ ) 
ranging from 1 to 10 for GSH.

\subsection{Extraction procedures}

An aqueous solution containing $1.0 \times 10^{-7}-2.0 \times 10^{-4} \mathrm{M} \mathrm{Cu}, 5.0 \times 10^{-4} \mathrm{M} \mathrm{GSH}$, cysteine, or hydroxylamine, and $1.0 \times 10^{-1} \mathrm{M}(\mathrm{H}, \mathrm{Na}) \mathrm{ClO}_{4}$ was shaken with an equal volume of an organic solvent containing $1.2 \times 10^{-4}-5.0 \times 10^{-3} \mathrm{M} \mathrm{dmp}$, dmdpp, or bq for 5-240 min. After phase separation, the $\mathrm{pH}$ of the aqueous phase was measured, and the concentration of $\mathrm{Cu}$ in the aqueous phase was determined by FAAS. An aliquot of the organic phase was shaken with $1.0 \mathrm{M}$ nitric acid for $1 \mathrm{~h}$ to strip $\mathrm{Cu}$ into the aqueous solution, which was then analyzed by FAAS. The distribution ratio $(D)$ and the percent extraction $(\% E)$ of $\mathrm{Cu}$ were calculated from the $\mathrm{Cu}$ concentrations in the organic and the aqueous phase.

\section{Results and Discussion}

\subsection{Reduction of $\mathrm{Cu}(\mathrm{II})$ with reducing agents in aqueous solution}

The reduction of $\mathrm{Cu}(\mathrm{II})$ to $\mathrm{Cu}(\mathrm{I})$ was monitored by UV spectra upon the addition of reducing agents at $\mathrm{pH}$ 1-10. Figure 2 shows the UV spectra of the solutions obtained by adding a 10-times excess of the reducing agents to the $\mathrm{Cu}$ (II) solution at $\mathrm{pH} 7.4$ (for concentrations, see the figure legend). In the absence of reducing agents, $\mathrm{Cu}$ (II) (as chloride) exhibits a broad absorption band with a maximum at $280 \mathrm{~nm}$. New absorption bands with a peak at $260 \mathrm{~nm}$ and a shoulder at $300 \mathrm{~nm}$ were recognized in the presence of both GSH and cysteine, whereas hydroxylamine gave a quite broad spectrum but no maximum at $280 \mathrm{~nm}$.

The absorption bands at $260 \mathrm{~nm}$ and $300 \mathrm{~nm}$ in GSH and cysteine were attributed to complex formation of the $\mathrm{Cu}(\mathrm{I})$ ion with the thiol compounds $[10,11]$. The values of the half-cell potential of the GSH/glutathione disulfide(GSSG) and cysteine/cystine redox system were reported to be -0.262 and $-0.245 \mathrm{~V}$ at $\mathrm{pH} 7.0$ respectively [12], which were low enough to reduce the $\mathrm{Cu}(\mathrm{II})$ ion $(0.153 \mathrm{~V})$ in the aqueous solution. These observations support the following redox reaction proposed in the literature [13],

$$
2 \mathrm{Cu}^{2+}+6 \mathrm{GSH}^{-} \rightarrow 2 \mathrm{Cu}^{\mathrm{I}}(\mathrm{GS})_{2}^{3-}+\mathrm{GSSG}^{2-}+6 \mathrm{H}^{+},
$$

where $\mathrm{GS}^{2-}$ stands for monoprotonated glutathione.

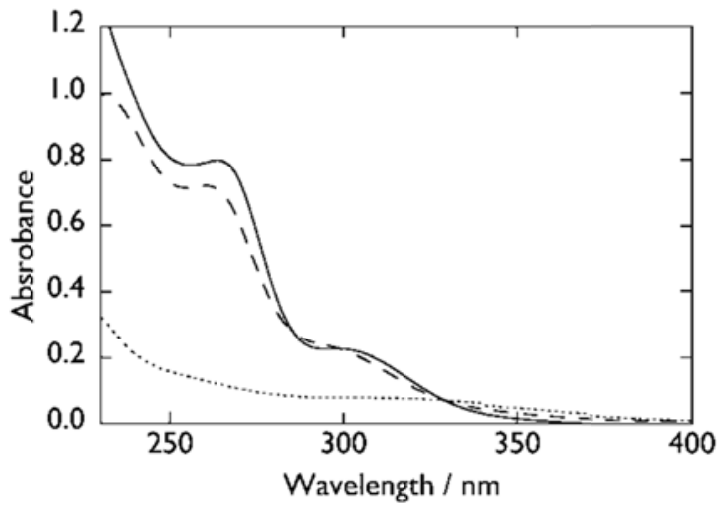

Figure 2. UV spectra of $\mathrm{Cu}(\mathrm{I})$ in the presence of different reducing agents. $[\mathrm{Cu}]=1.0 \times 10^{-4} \mathrm{M}$, $[$ reducing agent $]=1.0 \times 10^{-3} \mathrm{M},[$ HEPES $]=0.1 \mathrm{M}$, $\mathrm{pH}$ 7.4. (solid line) GSH, (dashed line) cysteine, (dotted line) hydroxylamine.

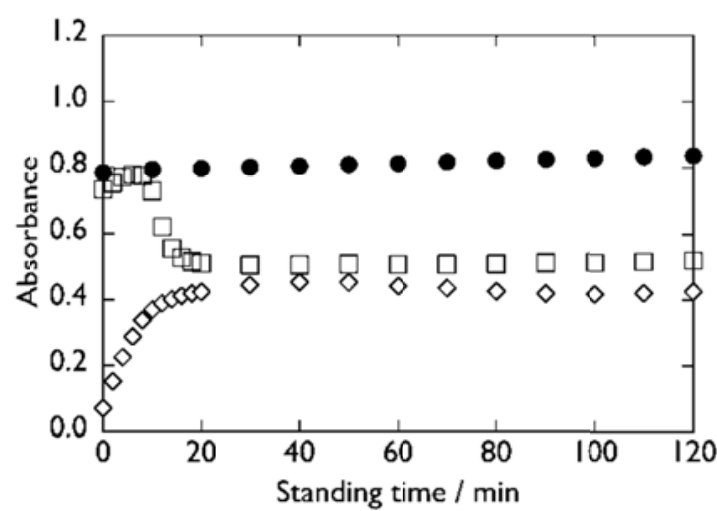

Figure 3. Effect of standing time on the absorbance of the $\mathrm{Cu}$ solution after the addition of different reducing agents. $[\mathrm{Cu}]=1.0 \times 10^{-4} \mathrm{M},[$ reducing agent $]=1.0 \times$ $10^{-3} \mathrm{M}, \quad[$ HEPES $]=0.1 \mathrm{M}, \mathrm{pH}$ 7.4. (•) $\mathrm{Cu}+\mathrm{GSH}$ at $260 \mathrm{~nm}, \quad(\square) \mathrm{Cu}+$ cysteine at $260 \mathrm{~nm}, \quad(\diamond)$ $\mathrm{Cu}+$ hydroxylamine at $280 \mathrm{~nm}$.

Figure 3 shows the time dependency of the absorbances at $260 \mathrm{~nm}$ in the presence of GSH and 
cysteine, and at $280 \mathrm{~nm}$ in hydroxylamine. In the hydroxylamine case, an increase in the absorbance at $280 \mathrm{~nm}$ is observed within $20 \mathrm{~min}$ and is ascribed to the autoxidation of $\mathrm{Cu}(\mathrm{I})$ to $\mathrm{Cu}(\mathrm{II})$. On the other hand, $\mathrm{Cu}(\mathrm{I})$-cysteine shows a marked decrease in the absorbance at $260 \mathrm{~nm}$ after 10 min under aerobic conditions, i.e., the decay of the $\mathrm{Cu}(\mathrm{I})$-cysteine complex. When the same experiment was performed with GSH, the absorbances at $260 \mathrm{~nm}$ and $300 \mathrm{~nm}$ were unchanged up to $6 \mathrm{~h}$, indicating that the oxidation state of copper remains univalent for several hours even under aerobic conditions. Consequently, GSH is an effective reducing and complexing agent to reduce $\mathrm{Cu}(\mathrm{II})$ to $\mathrm{Cu}(\mathrm{I})$ and for stabilization of the $\mathrm{Cu}(\mathrm{I})$ state.

All the data given above are consistent with the formation of $\mathrm{Cu}(\mathrm{I})$-GSH complexes accompanied by the reduction of $\mathrm{Cu}(\mathrm{II})$ and with their continuous regeneration against the autoxidation of $\mathrm{Cu}(\mathrm{I})$ under aerobic conditions. In accordance with the interpretation given above, the length of time preceding the decay of the complexes (indicated by the absorbance at $260 \mathrm{~nm}$ ) is strictly related to the excess amount of GSH. Indeed, the $260 \mathrm{~nm}$ absorbance of $\mathrm{Cu}(\mathrm{I})-\mathrm{GSH}$ at $\mathrm{pH} 7.4$ remains the same for 2, 4, and $6 \mathrm{~h}$ with $[\mathrm{GSH} /[\mathrm{Cu}(\mathrm{II})]$ ratios of 5,7 , and 10 , respectively. This result leads to a convenient method for the preparation of the aqueous $\mathrm{Cu}(\mathrm{I})$ solution under aerobic conditions. At high GSH concentrations, the presence of $\mathrm{Cu}(\mathrm{I})$ prepared in the aqueous phase lasts longer up to $6 \mathrm{~h}$, at which time almost all the GSH was oxidized to GSSG in the reduction of $\mathrm{Cu}(\mathrm{II})$ and the autoxidation. It is, however, recognized that the existence of $\mathrm{Cu}(\mathrm{I})$ is $\mathrm{pH}$ dependent. In the lower $\mathrm{pH}$ region, the existence of $\mathrm{Cu}(\mathrm{I})$ was slightly increased up to $8 \mathrm{~h}$ at $\mathrm{pH} 5$ or 6 . In contrast, the existence of $\mathrm{Cu}(\mathrm{I})$ was less than $1 \mathrm{~h}$ above $\mathrm{pH} 9$ (figure not shown). It is suggested that the decrease in the $\mathrm{Cu}(\mathrm{I})$ presence at high $\mathrm{pH}$ is due to the dissociation of the thiol group of GSH ( $\mathrm{p} K_{\mathrm{a}}=9.43$ [13]) and the formation of GSSG. Hence, the aqueous solution of $\mathrm{Cu}(\mathrm{I})$ for extraction was prepared at below $\mathrm{pH} 8$.

\subsection{Extraction behavior of $\mathrm{Cu}(\mathrm{I})$ in the presence of GSH}

Extraction of $\mathrm{Cu}(\mathrm{I})$ with $5.0 \times 10^{-4} \mathrm{M}$ bidentate amines (L) such as dmp, dmdpp, and bq in DCE was studied in the presence of $5.0 \times 10^{-4} \mathrm{M} \mathrm{GSH}$ and $0.1 \mathrm{M}$ $(\mathrm{H}, \mathrm{Na}) \mathrm{ClO}_{4}$. The $\mathrm{Cu}(\mathrm{II})$ solution was initially added to the aqueous phase just before shaking. The extraction curves with these amines are shown in Figure 4. High extractability was obtained with dmp and dmdpp but the extractability with bq was low. The difference observed among these amines is primarily explained by the stability of the $\mathrm{Cu}(\mathrm{I})$-L complexes; i.e., $\log \beta_{2}$ (in water) $=19.1$ for dmp [14], 19.8 for dmdpp [15], and 16.5 for bq [14]. In addition, the extractability of $\mathrm{Cu}(\mathrm{I})$ was found to be dependent on the

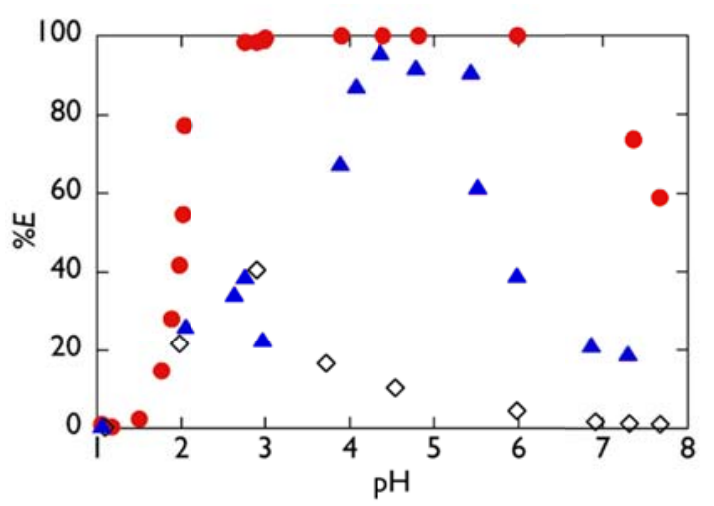

Figure 4. Extraction of $\mathrm{Cu}(\mathrm{I})$ with $5.0 \times 10^{-4} \mathrm{M}$ bidentate amines in DCE in the presence of $5.0 \times 10^{-4}$ $\mathrm{M} \mathrm{GSH}$ and $0.10 \mathrm{M}(\mathrm{H}, \mathrm{Na}) \mathrm{ClO}_{4} \cdot \quad[\mathrm{Cu}]=5.0 \times 10^{-5} \mathrm{M}$, $[$ buffer $]=0.01 \mathrm{M}$, shaking time $=30 \mathrm{~min} . \quad(\bullet) \mathrm{dmp}$, $(\mathbf{\Lambda})$ dmdpp, (৩) bq. shaking time in a certain $\mathrm{pH}$ range. The $\% E$ values for every amine were somewhat increased by prolonging the shaking time by $60 \mathrm{~min}$, e.g., $\% E=93$ at $\mathrm{pH} 7.4$ for $\mathrm{dmp}, \% E=35$ at $\mathrm{pH} 7.4$ for dmdpp, $\% E=6$ at $\mathrm{pH} 7.3$ for bq. This suggests that the ligand exchange between $\mathrm{Cu}(\mathrm{I})-\mathrm{GSH}$ and $\mathrm{L}$ in the aqueous phase is relatively slow (cf. Figure 5). Since the distribution constant of hydrophobic amines such as dmdpp and bq must be very high, although no data have been reported, the aqueous concentration 

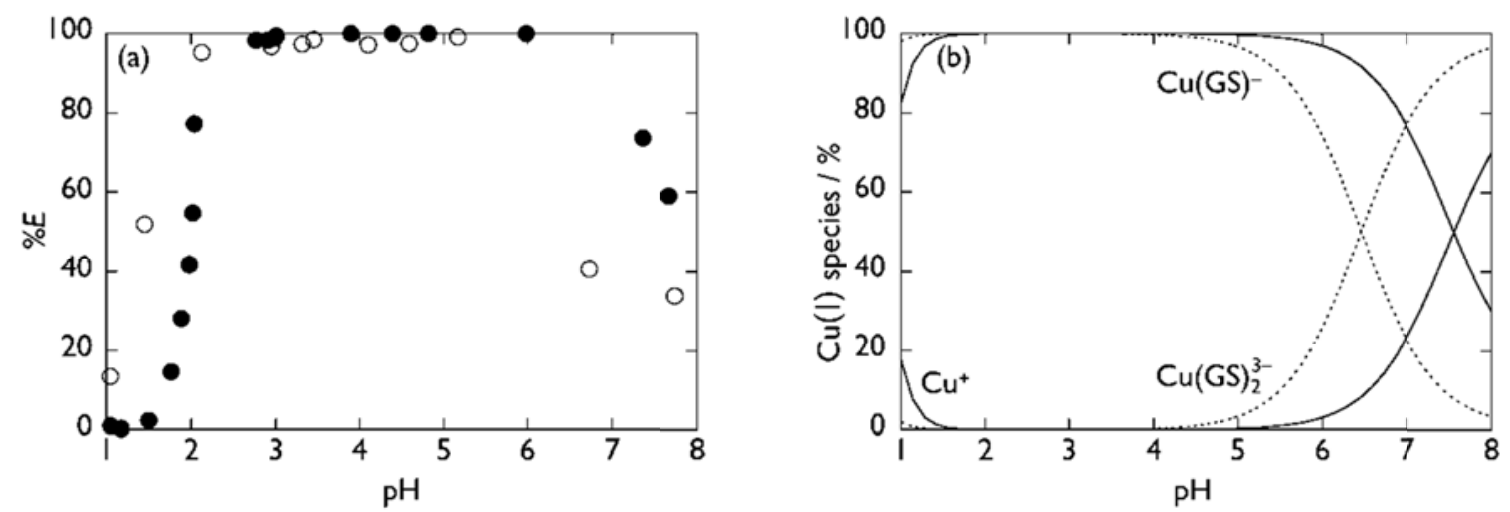

Figure 5. (a) Effect of the GSH concentration in the extraction of $\mathrm{Cu}(\mathrm{I})$ with $5.0 \times 10^{-4} \mathrm{M}$ dmp in DCE in the presence of $0.1 \mathrm{M} \mathrm{ClO}_{4}^{-} . \quad[\mathrm{Cu}]=5.0 \times 10^{-5} \mathrm{M}, \quad[\mathrm{GSH}]=(\bullet) 5.0 \times 10^{-4} \mathrm{M}$ and (o) $5.0 \times 10^{-3} \mathrm{M}$. (b) Fraction of $\mathrm{Cu}(\mathrm{I})$ species as a function of $\mathrm{pH} . \quad[\mathrm{Cu}]_{\mathrm{ini}}=5.0 \times 10^{-5} \mathrm{M},[\mathrm{GSH}]_{\mathrm{ini}}=($ solid lines $) 5.0 \times 10^{-4} \mathrm{M}$ and (dotted lines) 5.0 $\times 10^{-3} \mathrm{M}$.

of dmdpp and bq is much lower than that of dmp. This probably affects the extractability of $\mathrm{Cu}(\mathrm{I})$ with different $\mathrm{L}$ at the shaking time of $30 \mathrm{~min}$ as shown in Figure 4. In fact, the \%E value in the dmp system reached more than $98 \%$ within $5 \mathrm{~min}$ at around $\mathrm{pH} 4$ and agreed with that expected from the back extraction because the percent back-extraction obtained was 1-2\% at $\mathrm{pH} 3-6$. Therefore, it is suggested that extraction equilibrium in the dmp system was reached under the above conditions.

The effects of the concentration of GSH in the aqueous phase and dmp in the organic phase on the extraction of $\mathrm{Cu}(\mathrm{I})$ were investigated. As shown in Figure 5(a), when the initial GSH concentration is high, a higher extractability at low $\mathrm{pH}$ but a lower extractability at high $\mathrm{pH}$ are obtained. Since the $\mathrm{Cu}(\mathrm{I})$ ions are present as GSH complexes in the aqueous phase as described above, GSH essentially competes with dmp and acts as a masking agent for $\mathrm{Cu}(\mathrm{I})$. The concentration of GSH complexing anions increases with an increase in $\mathrm{pH}$ because the $\mathrm{p} K_{\mathrm{a}}$ of GSH is $2.43,3.48,8.62$ and 9.43 [13]. On the other hand, quantitative extraction of $\mathrm{Cu}(\mathrm{I})$ was achieved from $\mathrm{pH} 2$ to 8 when the dmp concentration was increased to $5.0 \times 10^{-3} \mathrm{M}$ (figure not shown), indicating the expected concentration dependency of $\mathrm{dmp}$ on the extraction efficiency of $\mathrm{Cu}(\mathrm{I})$. In Figure 5(b), the theoretical distribution of the $\mathrm{Cu}(\mathrm{I})$ species in the presence of GSH in the aqueous phase is given as a function of $\mathrm{pH}$. The molar fraction values of the $\mathrm{Cu}(\mathrm{I})$ species were calculated using the $\mathrm{p} K_{\mathrm{a}}$ of GSH and the stability constants $\left(\beta_{1}\right.$ and $\left.\beta_{2}\right)$ for the $\mathrm{Cu}(\mathrm{I})$-GSH complexes [13]. The extraction curves in Figure 5(a) correspond well to the distribution curves of the $\mathrm{Cu}(\mathrm{I})$ species in Figure 5(b). The main species, $\mathrm{Cu}(\mathrm{GS})^{-}$, can readily react with dmp and be extracted as a dmp complex into the organic phase, while the $\mathrm{Cu}(\mathrm{GS})_{2}{ }^{3-}$ species seems to resist a formation of the dmp complex in the higher $\mathrm{pH}$ region.

The substoichiometric extraction of $\mathrm{Cu}(\mathrm{I})$ with $\mathrm{dmp}$ or $\mathrm{ClO}_{4}{ }^{-}$in the presence of $\mathrm{GSH}$ was used to determine the composition of the extracted $\mathrm{Cu}(\mathrm{I})$ complex. The extraction of $\mathrm{Cu}(\mathrm{I})$ with a substoichiometric concentration $\left(1.0 \times 10^{-4} \mathrm{M}\right)$ of $\mathrm{dmp}$ in the presence of $1.0 \times 10^{-1} \mathrm{M} \mathrm{ClO}_{4}^{-}$and $5.0 \times$ $10^{-4} \mathrm{M} \mathrm{GSH}$ in the aqueous phase at $\mathrm{pH} 4$ was applied to a series of solutions containing different amounts of $\mathrm{Cu}(\mathrm{I})$. Figure 6(a) shows that the $\mathrm{Cu}(\mathrm{I})$ concentration in the organic phase increases with the increase in the amount of $\mathrm{Cu}(\mathrm{I})$ in the aqueous phase up to the equivalence point of $[\mathrm{Cu}(\mathrm{I})] /[\mathrm{dmp}]=0.5$. Beyond this point, a constant amount of $\mathrm{Cu}(\mathrm{I})$ is extracted into the organic phase, i.e., substoichiometric extraction 
was achieved. Its reproducibility was high at a relative standard deviation (RSD) value of $0.97 \%$.
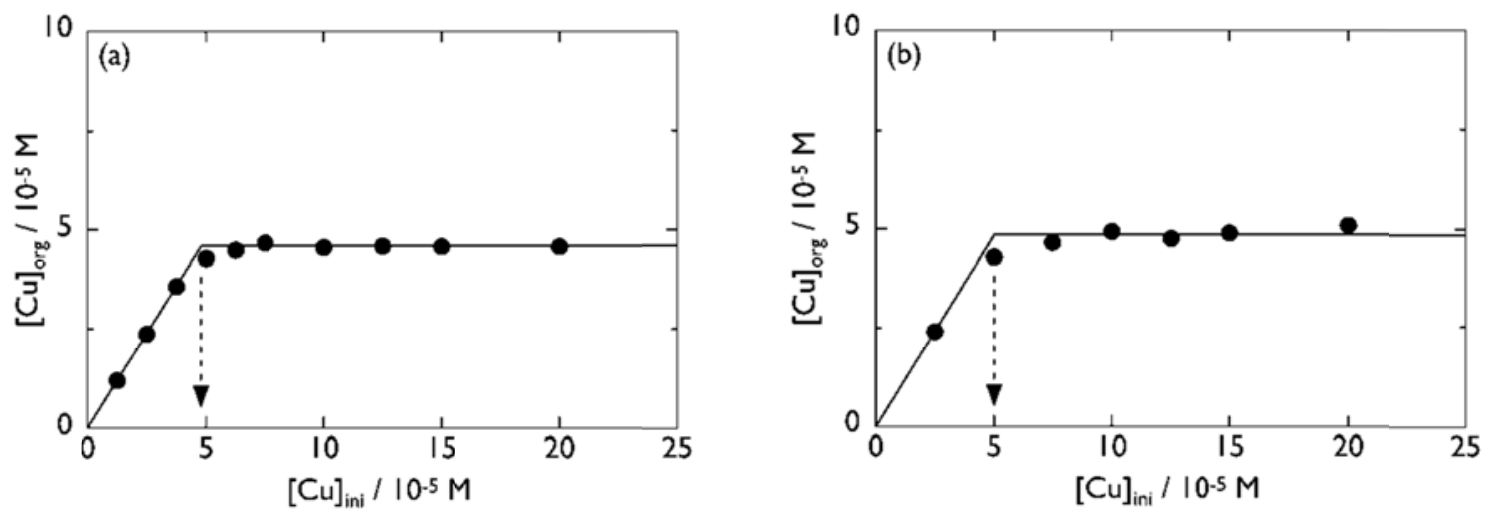

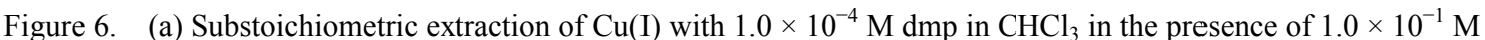
$\mathrm{ClO}_{4}{ }^{-}$and $5.0 \times 10^{-4} \mathrm{M} \mathrm{GSH}$. pH 4.09 - 4.32. (b) Substoichiometric extraction of $\mathrm{Cu}(\mathrm{I})$ with $5.0 \times 10^{-5} \mathrm{M} \mathrm{ClO}_{4}{ }^{-}$in the presence of $5.0 \times 10^{-4} \mathrm{M} \mathrm{dmp}$ in $\mathrm{CHCl}_{3}$ and $5.0 \times 10^{-4} \mathrm{M} \mathrm{GSH}$. pH $=4.14-4.33$, ionic strength $=0.1 \mathrm{M}$ $\left((\mathrm{H}, \mathrm{Na})_{2} \mathrm{SO}_{4}\right)$.

Consequently, as expected, the extracted $\mathrm{Cu}(\mathrm{I})$-dmp complex was confirmed to be $\mathrm{Cu}(\mathrm{dmp})_{2}{ }^{+}$. Also Figure 6(b) shows the substoichiometric extraction of $\mathrm{Cu}(\mathrm{I})$ using a combination of the substoichiometric concentration $\left(5.0 \times 10^{-5} \mathrm{M}\right)$ of $\mathrm{ClO}_{4}^{-}$and an excess $\left(5.0 \times 10^{-4} \mathrm{M}\right)$ of $\mathrm{dmp}$ in the presence of $5.0 \times 10^{-4} \mathrm{M}$ $\mathrm{GSH}$ at $\mathrm{pH}$ 4. A constant amount of $\mathrm{Cu}(\mathrm{I})$ is extracted reproducibly (2.37\% as RSD) after the equivalence point of $[\mathrm{Cu}(\mathrm{I})] /\left[\mathrm{ClO}_{4}^{-}\right]=1$. These results provide evidence of the extraction of the ion-pair complex, $\mathrm{Cu}(\mathrm{dmp})_{2} \mathrm{ClO}_{4}$.

\section{Conclusion}

It was found that GSH is an effective reducing agent for the preparation of aqueous $\mathrm{Cu}(\mathrm{I})$ solutions. The time-course measurement of the absorbance change indicate that the reduced state of $\mathrm{Cu}(\mathrm{I})$ is stabilized by the complexation with GSH even under aerobic conditions for up to several hours. The result obtained in this study demonstrates that quantitative extraction of $\mathrm{Cu}(\mathrm{I})$ from the aqueous solutions can be accomplished in the presence of GSH. The present extraction method can be used for the substoichiometric extraction of $\mathrm{Cu}(\mathrm{I})$ with either $\mathrm{dmp}$ or $\mathrm{ClO}_{4}{ }^{-}$and is expected to be applicable to the speciation of copper(I, II).

\section{Acknowledgement}

The authors thank Prof. N. Hirayama at Toho University and Dr. H. Nagatani at Kanazawa University for their helpful discussion. This study was supported by a Grant-in-Aid for Scientific Research (B) (No. 25288064) from Japan Society for the Promotion of Science (JSPS).

\section{References}

1) H. M. N. H. Irving, A. H. Nabilsi, Anal. Chim. Acta, 41, 505-513 (1968).

2) A. Nasu, A. Yoshikawa, J. Noro, T. Sekine, Anal. Sci., 12, 411-418 (1996).

3) A. Nasu, S. Yamauchi, T. Sekine, Anal. Sci., 13, $903-911$ (1997).

4) A. Nasu, K. Kato, T. Sekine, Bull. Chem. Soc. Jpn., 71, 2141-2148 (1998). 
5) D. H. Wilkinson, G. F. Smith, Anal. Chim. Acta, 9, 538-545 (1953).

6) A. R. Gahler, Anal. Chem., 26, 577-579 (1954).

7) G. F. Smith, W. H. Mccurdy, Jr, Anal. Chem., 24, 371-373 (1952).

8) G. F. Smith, D. H. Wilkinson, Anal. Chem., 25, 510-511 (1953).

9) T. Sekine, Y. Hasegawa, Solvent Extraction Chemistry, Marcel Dekker, New York, 1977.

10) L. Pecci, G. Montefoschi, G. Musci, D. Cavallini, Amino Acids, 13, 355-367 (1997).

11) B. C. Gilbert, S. Silvester, P. H. Walton, J. Chem. Soc., Perkin Trans. 2, 1999, 1115-1121.

12) K. K. Millis, K. H. Weaver, D. L. Rabenstein, J. Org. Chem., 58, 4144-4146 (1993).

13) R. Öasterberg, R. Ligaarden, D. Persson, J. Inorg. Biochem., 10, 341-355 (1979).

14) B. R. James, R. J. P. Williams, J. Chem. Soc., 1961, 2007-2019.

15) Z. Xia, J. Brose, S. Schimo, S. M. Ackland, S. La Fontaine, A. G. Wedd, J. Biol. Chem., 286, 11047-11055 (2011). The stability constant for $\mathrm{Cu}^{\mathrm{I}}(\mathrm{dmdpp})_{2}$ is not available. The value for the closely related bis-(2,9-dimethyl-4,7-diphenyl-1,10-phenanthroline disulfonate)copper(I) complex, log $\beta_{2}=19.8$, was cited. 